\title{
Urban Economic Openness and IPO Underpricing
}

\author{
Gianluca Marcato $^{1}$ - Stanimira Milcheva ${ }^{1}$. \\ Chen Zheng $^{1}$ (D)
}

(C) The Author(s) 2017. This article is an open access publication

\begin{abstract}
This paper represents a first attempt to employ a macroeconomic approach to explain the high and varying IPO underpricing within a single emerging market. We examine the empirical impact of trade openness on the short-run underpricing of initial public offerings (IPOs) using city-level data. Particularly, we argue that urban economic openness (UEO) has a significant impact on the productivity and on prices of both direct and indirect real estate due to productivity gains of companies in more open areas. This in turn positively affects the firm's profitability, enhancing the confidence in local real estate markets and future company performance, hence decreasing the uncertainty of the IPO valuation. As a result, issuers have less incentive to underprice IPO shares. We use a sample of Chinese real estate IPOs, which offer a suitable laboratory thanks to their strong geographic investment patterns focused locally and a country with a highly heterogeneous openness across regions. Controlling for traditional firm- and issuing-specific characteristics of IPOs that are used for developed markets and Chinese-related features (i.e. listing location and state ownership), we find the evidence that companies investing in economically more open areas experience less IPO underpricing. Our results show great explanatory power and are robust to different specifications.
\end{abstract}

Keywords IPO underpricing · Urban economic openness $\cdot$ Real estate

Chen Zheng

c.zheng@ pgr.reading.ac.uk

Gianluca Marcato

g.marcato@henley.reading.ac.uk

Stanimira Milcheva

s.milcheva@henley.reading.ac.uk

1 Real Estate \& Planning, Henley Business School, University of Reading, Reading, UK 


\section{Introduction}

The underpricing of initial public offerings (IPOs) in emerging markets is significant and previous research applying models used in developed markets has failed to explain this phenomenon and its cross-sectional variation-see Mok and Hui (1998), Chan et al. (2004), Gao (2010) and Tian (2011). In fact, most studies suggest that IPO underpricing is a result of the issuing firm's valuation and IPO underwriting process. According to the classic information theory, firm-specific features (e.g. size and age) reflect the level of uncertainty of the firm's valuation and, following a behavioural argument, the pre-IPO market performance represents the investors' sentiment about this uncertainty. Over the last two decades a new stream of literature has shown that the level of trade openness (or integration in global markets) experienced by a region affects the pricing of assets located in that region. Hence, we expect that the openness (or integration) of the region where a company operates should impact on its pricing. We build on this evidence and combine the two research streams to explain the IPO underpricing puzzle experienced in emerging markets using a macroeconomic approach.

Trade openness can affect IPO performance in several ways. In particular, we examine urban economic openness (UEO), which is defined as the degree of trades a certain region or urban area within a country has with foreign countries. The UEO of a company would then be measured as the relative trade between cities where the issuing firm invests and their foreign counterparties. We argue that UEO could affect the company's IPO valuation through different channels. Firstly, a city with higher openness should experience a more pronounced growth in productivity and output. As a consequence, the demand for real estate increases. Given the short-term inelastic housing supply, property prices increase and they therefore drive the valuation of companies up. Secondly, a company operating in a city with higher UEO could benefit from the increase in local real estate prices through the Balassa-Samuelson effect. For the first time, Balassa (1964) and Samuelson (1964) explore the connection between trade openness and the market of non-tradable goods. When international trades increase, the tradable sector experiences a greater productivity increase than the nontradable sector due to the more efficient information spillover, bigger market size and faster technology development. This would lead to a higher output in the tradable sector than in the non-tradable one. However, as labour is mobile across regions and industries, the average wage should equally increase — see Samuelson (1964), Dollar (1992), Sachs and Warner (1995), Edwards (1998) and Miller and Upadhyay (2000) As a result, there will be an increase in the relative prices of non-tradable goods as compared to tradable goods. Considered as the largest non-tradable asset, real estate prices should increase in areas with higher UEO, leading to a rise in the profitability of real estate companies. ${ }^{1}$ Thirdly, companies could increase their profitability not only indirectly through the change in their asset values, but also directly through the increase in overall productivity in regions with high UEO ((Demsets 1973, Peltzman 1977, Eilon 1985, Jovanovic 1982 , Stierwald 2010). ${ }^{2}$ Finally, an increase in the UEO of a city can also

\footnotetext{
${ }^{1}$ The Balassa-Samuelson effect is supported by empirical studies showing that the productivity growth in real output would finally increase the relative price of non-tradable goods - see De Gregorio et al. (1994) and Deloach (2001).

${ }^{2}$ Please refer to Dollar (1992), Sachs and Warner (1995), Edwards (1998) and Miller and Upadhyay (2000) for the impact of trade openness on productivity.
} 
lead to a rise in property prices by fostering an increase of foreign (and domestic) real estate investments in more open regions, due to an easier flow of capital-Saleryd and Vlachos (2002), Beck (2002), Basu and Morey (2005), Law (2008), Baltagi et al. (2009), Lim and Kim (2011) and Kim et al. (2012). Overall, the above mechanisms demonstrate how UEO can decrease the uncertainty about the company's future earnings, leading to a more accurate firm valuation. As a result, the underpricing is lowered.

In particular, we believe that Chinese real estate companies represent a suitable laboratory to explain the IPO underpricing puzzle in emerging markets using a macroeconomic approach. Firstly, since the IPO underpricing in this sector is high and varies across companies, the significant variation of openness across Chinese regions may be related to a different geographical investment focus of issuing firms. China is a developing country with cities rich in development opportunities and almost all real estate companies include a significant development portfolio (reported as inventory or intangible asset in financial reports along with buildings held as investments). The land is owned by the central government and each company bids for landuse rights, whose value is reported in the IPO prospectus. Secondly, because companies need to bid for land-use rights from local governments, most real estate firms tend to concentrate their businesses in one location where they believe they have informational advantages. This might be caused by future development opportunities in a city, as well as connections with local governments and institutions to obtain land-use rights. In fact, Miao and Zhu (2005) show that Chinese real estate markets are still very much localized (with varying regional policies and regulations). As a consequence, the barriers to enter a new market are so high that most real estate companies prefer to remain focused in one region and compete with other local real estate companies than to diversify geographically. Finally, even if some companies operate across regions (normally two main areas represent a significant proportion of the overall portfolio) the real estate business (investing in physical nonmovable assets, i.e. buildings and land) allows us to identify the exact portfolio of locations where the business is operated. Consequently, an index of openness can be calculated for each company based on the locations where the company operates and the level of trade openness each location offers.

In our study, we collect data of Chinese real estate IPOs from 1992 to 2013 and find that, after controlling for firm- and issue-specific characteristics, UEO significantly and negatively affects IPO underpricing. Companies operating in cities with higher UEO experience less underpricing when they go public and this result remains robust once we account for IPO location, ownership structure or other local macroeconomic variables. Our findings can help issuers, underwriters and investors to better understand the dynamics of IPO markets in emerging markets using UEO. They also provide policy implications with regards to the ties between the local economy and the performance of regional firms and implications for state-owned companies going public. Finally, although focusing on Chinese real estate IPOs, our results could also apply to other countries and sectors with similar market structures.

The paper is structured as follows: the next section presents a literature review that is relevant to our hypothesis. Section 3 describes the data and the methodology. Empirical results and robustness tests are discussed in Section 4, while main conclusions are presented in the last section. 


\section{Literature Review}

Empirical evidence shows that an average positive initial return for IPOs - the gap between closing price on the first-trading day and initial offer price - exists, implying that the offer price, set by the firm and underwriters is lower than the price that the market is willing to pay (at least in the short-run). This phenomenon represents a financial puzzle known as IPO underpricing, which has been explained mainly from two angles so far: the classic information asymmetry theory (i.e. the underpricing is pre-market determined) and the behavioural argument (i.e. the underpricing is driven by market sentiment). Three main parties - issuers, underwriters and investors - are involved in an IPO event. Classic explanations follow the information asymmetry theory (Rock 1986) which assumes that a certain group of investors have better information about the firm's value than other investors, underwriters or issuers. Because rationing by underwriters exists, the uninformed investors cannot obtain the underpriced shares and eventually become reluctant to participate in the IPO. As a result, the initial offer needs to be underpriced enough to attract enough investors and compensate for the asymmetric information bias. The famous winner's curse theory (Beatty and Ritter 1986) and information extraction theory (Benveniste and Spindt 1989) were built upon this broader literature. The former shows that, if investors were allocated shares, they would think that those shares were mispriced and unwanted by other informed investors. As a result, uninformed investors would only request IPO shares when offerings were underpriced enough to compensate for their uncertainty. The latter, instead, shows that underwriters underprice shares on purpose to obtain useful information from informed investors in return. Furthermore, the signaling theory assumes that issuers are best informed about their company and underpricing is a strategy to signal to the public that the firm is of "good quality" and can recover the cost of underpricing in seasoned offerings, as opposed to "bad-quality" firms which cannot afford the cost of underpricing (Allen and Faulhaber 1989). Finally, behavioural arguments have started to become more popular. An example is offered by Loughran and Ritter (2002), where higher pre-IPO market return indicates the investors' sentiment and may lead to after-market demand driven high initial returns.

One one hand empirical studies focusing on developed markets find confirmation to these theories, on the other hand, they are less successful in explaining extremely high underpricing of IPOs in emerging markets. Relying purely on company-specific characteristics may yield weak and distorted results because underdeveloped institutional features would be missed. In China for example, the average underpricing of all IPOs between 1990 and 1993 was 289\% according to Mok and Hui (1998) and 178\% between 1993 and 1998 according to Chan et al. (2004). Tian (2011) also finds extremely high underpricing of 247\% in a sample of 1377 IPOs from 1992 to 2004 and argues that information asymmetry is far from being a major determinant. Similarly, Gao (2010) finds no significant relationship between the initial returns and proxies for information asymmetry.

With regards to real estate IPOs in particular, Chan et al. (2001) show that US REITs IPOs experience abnormally low underpricing compared to IPOs in other industries. One possible explanation rests in the presence of more individual and fewer institutional investors in REITs than in other industries as this may reduce the impact of informed investors. On the other hand, REITs may also behave more similarly to funds 
than to operating companies, and they generate low uncertainty leading to a low IPO underpricing (a common characteristic of funds in general). Finally, the characteristics of underlying assets of real estate companies might also represent a further explanation. The ownership structure and similarity with funds does not reflect the IPO market of Chinese real estate companies because the property market has received enough attention from institutional investors and the majority of companies are operating companies (including developments in their portfolio). As our study presents an analysis of IPO performance from a "non-tradable goods perspective", we believe that Chinese real estate IPOs offer an adequate laboratory to test our hypothesis focusing on the role of underlying assets.

The final stream of literature relevant to this work is related to globalisation and the linkages between openness and markets of tradable goods. First, empirical studies find that countries' foreign trade exposure leads to greater productivity growth - Dollar (1992), Sachs and Warner (1995), Edwards (1998) and Miller and Upadhyay (2000). Following the evidence that productivity is a major determinant of company's profitability_Demsets (1973), Eilon (1985), Jovanovic (1982), Peltzman (1977) and Stierwald (2010)_, Miller and Upadhyay (2000) use a panel data to assess the determinants of total factor productivity. By using the classic National Bureau of Economic Research (NBER) calculation of trade openness (total import and export as a share of GDP), they find that the effects of trade openness on total productivity are significantly positive. Moreover, for a sample of 29 provinces in China between 1981 and 2005, Jiang (2011) finds that UEO has direct positive effects on Chinese regional productivity growth, and this is consistent with previous country-level studies. In recent years, research has also shown that trade openness has an impact on the degree of financial market development. According to Rajan and Zingales (2003), an increase in both cross-country trades and capital flows leads to an increase in the degree of financial development. Saleryd and Vlachos (2002), Beck (2002) and Kim et al. (2012) find a reverse causal effect between trade openness and financial development (i.e. the increase in trade openness occurs following an increase in financial development). Finally, Law (2008) and Baltagi et al. (2009) find that trade openness and capital account openness jointly and positively affect the financial development in both the banking sector and the stock market in Malaysia. Law (2008), in particular, shows that the effect of trade openness on financial development is greater than that of capital account openness. Moreover, the effect of trade openness is significant in both the banking sector and stock market, while the effect of capital account openness is less so. By using panel data, Kukeli (2012) finds that trade openness is one of the most important determinants of a country's capital formation.

Within this stream, a group of studies examines the relationship between openness and stock market performance in emerging markets. Li et al. (2004) employ an openness approach to explain the increased firm-specific variation in the 1990s and find that capital market openness positively affects the firm-specific variation while trade openness positively affects the market variation. Basu and Morey (2005) argue that, once a country opens its trades to the world, stock prices start to follow a random walk whilst they were serially correlated beforehand. Following an increase in trade openness, the development in technology will be captured by the equilibrium stock prices leading to a decrease in excess returns and, eventually, an increase in stock market efficiency. Lim and Kim (2011) show that trade openness should boost firms' 
future profitability and reduce uncertainty. As a result, investors would react faster to the information on the market. Therefore, the trade openness would finally enhance the informational efficiency of the stock market. However, the authors also find that the de facto measure, i.e. classic NBER measure, has a significantly negative impact on stock return serial correlations but the alternative de jure measure, i.e. country's international trade freedom index constructed according to a country's trade policy, does not show any significance. As the de facto measure reflects real output and there is no de jure measure at city level in China, we use the de facto measure in our empirical analysis.

Being the biggest asset of the non-tradable goods market, real estate and its links with trade openness have already been studied. Initially, Bardhan et al. (2004) empirically test the relationship between trade openness and real estate rents using monthly data for 46 countries. For the measurement of openness, standard NBER indices are used. Results show that wage levels, population, and trade openness positively affect rents, and they are consistent with the Balassa-Samuelson effect. This research has been then extended to a regional level study by Wang et al. (2011) who analyze trade openness and real estate prices at the urban level. The study focuses on China, as it represents a good example of an emerging market with an urbanization rate increasing from 30\% in 1998 to $46 \%$ in 2008. The sample covers 35 cities from 1998 to 2006 and the authors find that real estate prices increase by $2.82 \%$ when UEO increases by $10 \%$. To appreciate its importance, between 1998 and 2006, 16\% of the increase in Chinese real estate prices is attributed to the increase of UEO alone. Bardhan et al. (2008) examine the effects of country-level trade openness on returns of securitized real estate by using a sample of 946 listed real estate companies from 16 countries. They find that trade openness has a significantly negative impact on the excess returns of real estate stocks, controlling for global and domestic variables. Case et al. (1999) point out that even though country-level factors were driving real estate performance, regional output was a more important determinant.

\section{Data and Methodology}

Our sample includes IPOs of Chinese real estate companies from 1992 to 2013. The Shanghai Stock Exchange was founded in 1990 and the Shenzhen Stock Exchange was founded in 1991. So, our sample traces back to almost the very beginning of stock markets in China in order to capture the changes in IPO performance throughout the economic cycles. The main IPO data is obtained from Thomson One. Due to the incomplete records of Chinese IPOs, especially those in the early years of our sample, most data has been manually collected from various local sources, such as the Shanghai Stock Exchange, Shenzhen Stock Exchange, Hong Kong Stock Exchange, Singapore Stock Exchange, as well as financial websites (e.g. jrj.com and sina.com). Firm-specific data (e.g. age, state ownership, land reserves, income and real estate assets) are collected manually form the issuers' IPO prospectus, which are obtained from different sources including Thomson One, the Hong Kong Exchange HKExnews (a designated website providing regulatory filings and disclosure of listed companies) and companies' websites (with the majority of prospectuses being in Chinese). Economic data (e.g. foreign trade volume and GDP) are extracted from the City Annual Statistical Reports, obtained from the China National Knowledge Infrastructure (CNKI) database. City Annual Statistical Reports are the official governmental reports of the local annual 
economic performance. CNKI is a key national e-publishing project in China that was started in 1996, approved by the Press and Publications Administration of the People's Republic of China (PRC) and backed by Tsinghua University.

In total, there are more than 150 listed Chinese real estate companies in the full database. However, some of them were not predominantly real estate companies when they went public and some others went public through a "back-door listing", whereby the company goes public by acquiring an already listed company. Hence, we were left with 70 IPOs meeting our selection criteria of being listed directly as a real estate IPO and having the full set of information for all the variables of interest. ${ }^{3}$

The dependent variable $\left(I N I R E_{i}\right)$ represents the initial return of company $i$, a widely recognized measure of IPO underpricing and computed as the percentage difference between the offer price $\left(O P_{i}\right)$ and the closing price on the first day of trading $\left(C P_{1 \text { day }, i i}\right)$ :

$$
\operatorname{INIRE}_{i}=\frac{C P_{1 \text { day }, i}-O P_{i}}{O P_{i}}
$$

The higher the initial return, the higher the IPO underpricing is. Some studies deduct the market performance between the issuing and the listing dates from the IPO initial returns to control for market effects. Since the average IPO underpricing in China is extremely high, the overall market performance is unlikely to affect the underpricing. Therefore, we keep the original form of measuring IPO underpricing. Instead, we will control for the pre-IPO market performance in different specifications. We also estimate model with the adjusted measure but results do not change and hence we do not report them.

The main variable of interest is urban economic openness (UEO), which is measured by the regional trade openness. As discussed above, we adopt the de facto measure by NBRE, which is computed as the sum of imports and exports as a percentage of GDP: Since most studies focus on a country-level analysis and use the NBER definition, we adjust the formula as required by our single country study to compute the city-level measure by using total annual imports and exports between city $j$ and its foreign counterparties and the city's annual GDP.

$$
U E O_{j}=\frac{\text { Imports }_{j}+\text { Exports }_{j}}{G D P_{j}}
$$

The amount of foreign trade of a city is recorded in the City Annual Statistical Reports by the local government and is expressed in US dollars. The total sum of imports and exports is converted into Chinese Yuan (RMB) by using the average annual US Dollar to Chinese Yuan exchange rate in the same year.

Most Chinese real estate companies focus their businesses in one area-usually one city - while some of them have businesses in several cities (often geographically close). Only very few big real estate companies run businesses widely spreading across China, mainly focusing on big developed cities such as Shanghai or Beijing which usually

\footnotetext{
${ }^{3}$ As we mentioned above, we focus on real estate IPOs as testing laboratory because other industries hardly show a localised business and a regional composition of the investment portfolio is not available. This is the reason why we cannot extend our sample to other industries or form a control sample to test the impact of UEO at firm level.
} 
have similar level of trade openness. Hence, for companies operating in more than one city, we obtain the UEO measure for one company as the weighted average of the individual UEO measures of the cities in which the company invests $\left(U E O_{j, i}\right)$. The weights are constructed as the ratio between the available land with land-use rights company $i$ has in city $j\left(\right.$ Land $\left._{j, i}\right)$ and the overall land with land-use rights company $i$ owns $\left(\right.$ Land $\left._{i}\right)$. The information regarding the locations of investments for each company and the information about land-use rights are manually extracted from IPO prospectuses and the financial reports before IPO. The UEO measure for company $i$ is then computed as follows:

$$
U E O_{i}=\frac{1}{\text { Land }_{i}} \sum_{j=1}^{m}\left[U E O_{j, i} \times \text { Land }_{j, i}\right]
$$

In our sample, $50 \%$ of companies operate assets locally in one city. The UEO for these companies does not require weighing and is simply the annual city-level foreign trade as a share of the annual city-level GDP. For the remaining companies, the majority is based in two different cities and $21 \%$ of companies have more than $50 \%$ of their businesses focused in one city. Overall, $90 \%$ of companies in our sample have at least $30 \%$ of their businesses in one city. As a robustness check, we also split the sample into companies operating in one city and companies operating in more than one city. We run separate estimations and we do not find significantly different results. Therefore, we present and discuss only results obtained with the overall sample.

In the remaining part of this section we present other variables normally included in related works and used here as control variables:

LNLAG is the natural logarithm of the time lag between the IPO issuing and listing dates. Most studies find that the longer the time lag, the higher the underpricing due to the increased uncertainty. The issuing dates are extracted from the prospectus and the listing dates are taken from the stock exchanges.

$L N P R O$ represents the natural logarithm of the proceeds (the product of the offer price and the number of shares offered). They are collected from Thomson One, Bloomberg and the stock exchange where the IPO is listed. According to the information asymmetry theory and winner's curse theory (Rock 1986; Beatty and Ritter 1986), the greater the information asymmetry is, the bigger the underpricing will be. Many studies find that the bigger the firm size the smaller the presence of information asymmetry is. $L N P R O$ is a proxy for firm size and it is expected to have a negative effect on the IPO underpricing.

ROREA represents the return on real estate assets for the year preceding the IPO. The return on assets has often been used to examine the effect of a company's earnings performance prior to the IPO on its IPO performance. To better capture the real estate characteristic, we use the return on real estate assets instead. The earnings from the real estate business are usually reported separately in the prospectus. The variable for the real estate asset size is manually collected and computed as the sum of the accounts of property, plant and equipment, investment properties, prepayment for the rent of the land and property, property held for sale, property under development and land reserves in the financial report before the IPO. 
$L N A G E$ is the natural logarithm of the firm age - i.e. time (years) elapsed between its foundation and the IPO date. It is also a proxy for the level of uncertainty. STATEO is a dummy variable denoting the state ownership. It equals 1 if the real estate company is state-owned before the IPO and 0 otherwise. It is commonly used in Chinese IPO studies as it reflects the impact of the special political system. CHINA is a dummy variable denoting the IPO location. It equals 1 if the company is listed in Mainland China, 0 otherwise. Note that in our study we refer to Chinese real estate companies as listed real estate companies whose business is in Mainland China, even if some of them might decide not to be listed on stock exchanges in Mainland China. In our sample, 33 companies were listed in Mainland China, 35 in Hong Kong and 2 in Singapore. According to Wong et al. (2013), Chinese real estate companies going public in Hong Kong experience much less underpricing than those listed in Mainland China due to a better market transparency and corporate governance reducing the information asymmetry.

$M R 30$ and MR60 represent the market performance in the 30 and 60 days before the IPO and 30-day pre-IPO market return is commonly used to proxy for market sentiment prior to an IPO. For example, the prospect theory - Loughran and Ritter (2002) - suggests that the higher market return during the pre-selling and IPO road show before the IPO is associated with a higher level of IPO underpricing because the investors' demand for IPOs is strong and prices would be pushed up. Unlike classic theories suggesting that public information available before IPOs should be fully reflected in the price, the prospect theory believes that the market momentum reflects the investors' sentiment and causes aftermarket investor-driven high initial returns and hence more IPO underpricing. The 30-day market return is commonly used to proxy for the market sentiment and has been found to be positively related to the IPO underpricing. In this study we use both 30-day and 60-day market returns as the Chinese stock market is far from being mature and there are more "noisy traders", meaning that market momentum is very likely to last longer.

$D A Y 30$ and DAY60 represent the numbers of other IPOs within the 30- or 60- day period preceding the IPO as shares of the total numbers of IPOs during the sample period, a proxy for the IPO waves.

Table 1 contains the description and summary statistics of the main variables. Chinese real estate IPOs are strongly underpriced with an average initial return of $103.85 \%$ over our sample period. There is also a significant variation in initial returns, with values ranging from $-7.3 \%$ to $980 \%$ and being consistent with previous literature. As expected, UEO differs significantly across companies, ranging between $3.06 \%$ and $551.8 \%$. This implies the existence of significant heterogeneity in the level of trade openness across Chinese cities. The variation comes from exports and imports with foreign countries, while city-level GDP growth rates usually follow country-level figures very closely and show a greater homogeneous pattern across cities.

The state ownership of the issuing company has been a popular approach to explain the extreme IPO short-run performance in China. The political system is different from developed countries and a strong government intervention in financial markets exists. Therefore, researchers argue that state ownership represents a negative signal on the firm's independent governance, indicating low transparency due to a higher possibility of manipulation and corruption within the firm. Therefore, state-owned companies are 


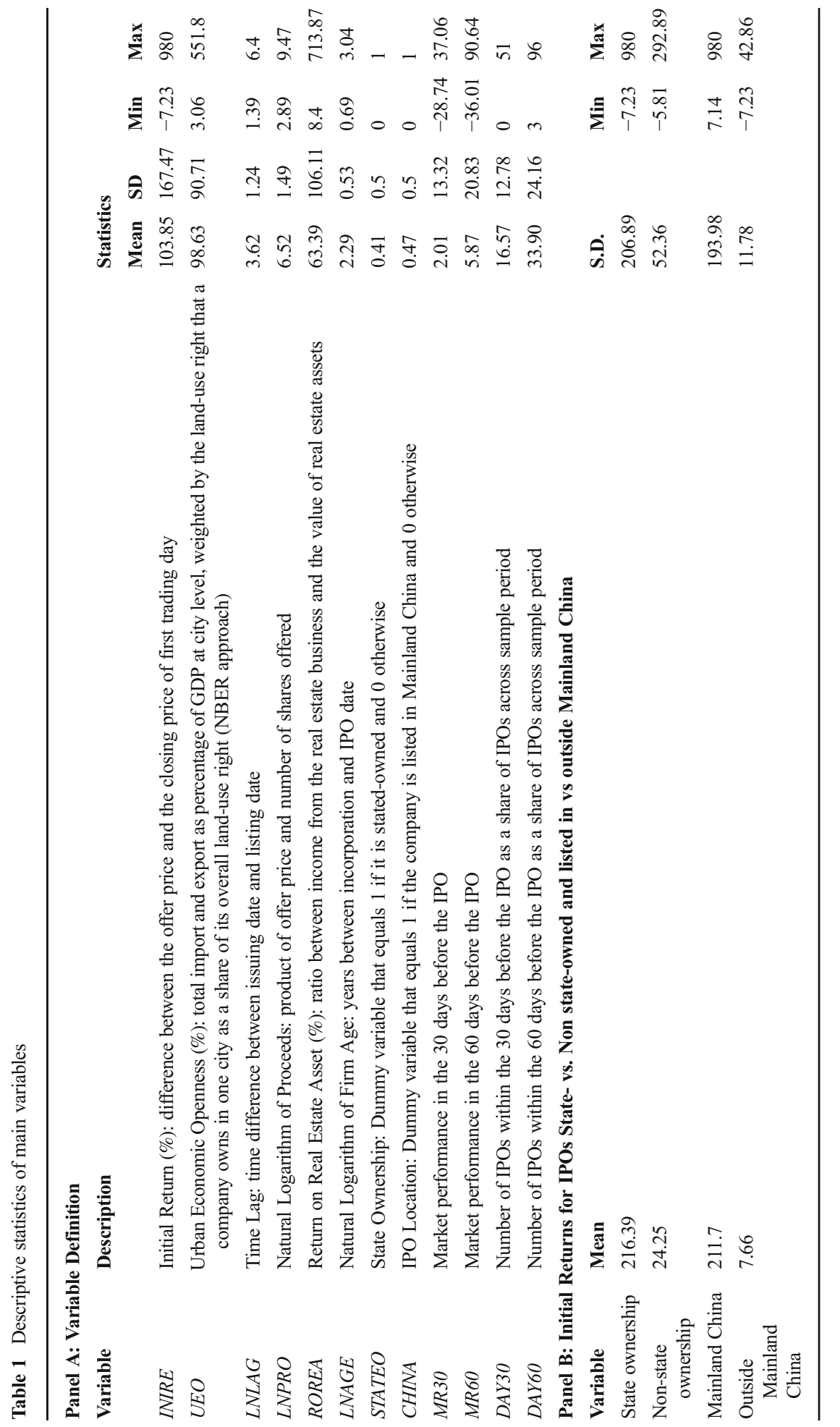


expected to experience more underpricing than privately owned ones. Following this argument, we summarize our data by state ownership. The first two rows in Panel B of Table 1 report the statistics of IPOs of state-owned and non-state-owned companies. Consistent with our arguments above, the average IPO initial return, standard deviation and interval of non-state-owned companies are much smaller than the ones of stateowned companies. Wong et al. (2013) study the influence of IPO location on IPO underpricing of Chinese developers, arguing that the IPO location (Mainland China vs Hong Kong) represents a signal for developers' quality and levels of transparency. Since our sample includes developers as well as investors, we have access to firms listed in three different stock exchanges: Mainland China (35 companies), Hong Kong (33 companies), and Singapore ( 2 companies only). The last two rows in Panel B of Table 1 report the statistics of initial returns by IPO location. Our results are consistent with the findings by Wong et al. (2013) as the initial returns of the IPOs listed in Mainland China are much larger than those listed outside. ${ }^{4}$

However, since the state-ownership and IPO location variables are highly correlated $(0.72)$ as they may proxy for the same factor, we decide to use them alternatively in our estimations and we explain the listing preference of different ownership structures as follows: stated-owned companies are more likely to choose to be listed in Mainland China because they can use their political connection more efficiently than in other countries/markets, while private companies try to avoid the political manipulation in Mainland China and choose more competitive and transparent markets like Hong Kong and Singapore. As a robustness check, we also estimate our model including both variables and main results for our variable of interest (UEO) do not change significantly and hence we do not report them.

Beatty and Ritter (1986) argue that the underwriters' subsequent market shares decrease if they fail to price the IPO shares at an adequate level. A substantial amount of empirical studies support the negative relationship between the underwriters' reputation and the level of IPO underpricing. However, the effect of the underwriters' reputation remains inconclusive as the reversed relationship has also been documented not only in the US market but also in other developed markets. If we consider Chinese IPOs where the market is far more exposed to the political system, the role of the underwriters' reputation seems to be less significant. While the majority of IPO studies in China have ignored the underwriters influence, Su and Bangassa (2011) follow the classic theories and systematically examine the effects of the underwriters' reputation on IPO underpricing in China and find little influence. Despite the lack of information on Chinese investment banks, unlike Su and Bangassa (2011) and many other studies on underwriters' reputation, our sample includes IPOs from more than one market, with IPOs listed in Mainland China often using Chinese investment banks and those listed in Hong Kong and Singapore often using international investment banks, which means it is difficult to rank the underwriters. The nature of our sample makes the measurement of the reputation very much correlated with state ownership and the dummy on the

\footnotetext{
${ }^{4}$ As there are only two IPOs listed in Singapore and the others are either listed in Mainland China or Hong Kong, it is difficult to include another location dummy here. However, in order to check that our inferences are not affected, we have also ran all the estimations with a sample excluding these two IPOs listed in Singapore and the main results do not change much.
} 
stock exchange where companies are listed. Hence, we do not include this variable in our study. ${ }^{5}$

\section{Main Empirical Results}

\section{Ordinary Least Squares (OLS) Estimation}

We first test to what extent UEO affects IPO underpricing by using an ordinary least squares (OLS) regression. To control for the market effects, 30-day and 60-day windows are included respectively. The specification is as follows:

$$
\operatorname{INIRE}_{i}=\beta_{0}+\beta_{U E O} \times U E O_{i}+\beta_{i} \times X_{i}+\varepsilon_{i}
$$

where $X_{i}$ is a vector of other explanatory variables and $\beta_{i}$ are the coefficients to be estimated. Firstly, we check for homoskedastic error terms by using the Breusch-Pagan test. As we reject the null hypothesis that the variance of the error term is constant across observations, the standard errors presented below the coefficients are corrected for heteroskedasticity.

The main results are presented in Table 2. There are two sets of OLS regressions Group A controls for 30-day market variables and Group B controls for 60-day market variables. As expected, the coefficients for urban economic openness are negative throughout all specifications and they are significant at 5\% level. A $10 \%$ increase in the UEO results in a $2.56 \%$ to $3.08 \%$ decrease of IPO initial returns depending upon the specifications. This supports our research hypothesis that real estate companies with investments in more trade-open areas have less incentive to underprice their IPOs. Holding other factors constant, a real estate company would experience $2.56 \%$ to $3.08 \%$ less IPO underpricing if it runs its real estate business in a city where the level of trades with foreign countries is $10 \%$ higher. The greater regional trade openness increases the future profitability and reduces the valuation uncertainty, a key determinant of the level of IPO underpricing. According to the Balassa-Samuelson effect, trade openness will eventually increase the prices of non-tradable products including real estate assets. Besides, trade openness positively affects the productivity which is an important determinant of a company's profitability. In addition, the demand for real estate could rise as a direct consequence of the increase in foreign and domestic investments into real estate given an improvement in capital flows. Therefore, investors in companies operating in areas with higher UEO tend to be more confident about the local real estate market and the company's future profitability, which leads to less uncertainty about the company' valuation. As a result, issuers will have less incentive to underprice the IPO shares. ${ }^{6}$

Consistent with the majority of IPO studies, we find that the time lag between issuing and listing positively affects the initial returns of IPOs - i.e. the longer it takes to

\footnotetext{
5 This also represents a reason why cross-country studies do not normally control for underwriters' reputation.

${ }^{6}$ The explanation power of the trade openness in the cross-country variation of IPO underpricing could be examined in future study, which requires well control of other country-level explanatory variable such as currency freedom, legal system, efficiency of the market and other demographic variables.
} 
Table 2 Baseline results: IPO underpricing and UEO

\begin{tabular}{|c|c|c|c|c|}
\hline Model: & A1 & $\mathrm{A} 2$ & $\mathrm{~B} 1$ & B2 \\
\hline$U E O$ & $\begin{array}{l}-0.256^{* *} \\
(-2.05)\end{array}$ & $\begin{array}{l}-0.299 * * \\
(-2.35)\end{array}$ & $\begin{array}{l}-0.273^{* *} \\
(-2.13)\end{array}$ & $\begin{array}{l}-0.308^{* *} \\
(-2.42)\end{array}$ \\
\hline$L N L A G$ & $\begin{array}{l}44.573^{* * * *} \\
(2.76)\end{array}$ & $\begin{array}{l}49.076^{* * * *} \\
(3.06)\end{array}$ & $\begin{array}{l}35.356^{* * * *} \\
(2.79)\end{array}$ & $\begin{array}{l}39.792 * * * \\
(3.27)\end{array}$ \\
\hline$L N P R O$ & $\begin{array}{l}-45.863^{* *} \\
(-2.55)\end{array}$ & $\begin{array}{l}-34.772^{*} \\
(-1.70)\end{array}$ & $\begin{array}{l}-44.582 * * \\
(-2.65)\end{array}$ & $\begin{array}{l}-33.790^{*} \\
(-1.81)\end{array}$ \\
\hline ROREA & $\begin{array}{l}0.299 * \\
(1.76)\end{array}$ & $\begin{array}{l}0.279 * \\
(1.74)\end{array}$ & $\begin{array}{l}0.264 \\
(1.38)\end{array}$ & $\begin{array}{l}0.242 \\
(1.32)\end{array}$ \\
\hline$L N A G E$ & $\begin{array}{l}-14.287 \\
(-0.50)\end{array}$ & $\begin{array}{l}-15.796 \\
(-0.55)\end{array}$ & $\begin{array}{l}-15.470 \\
(-0.56)\end{array}$ & $\begin{array}{l}-16.912 \\
(-0.62)\end{array}$ \\
\hline STATEO & $\begin{array}{l}78.967^{* *} \\
(2.48)\end{array}$ & & $\begin{array}{l}71.735^{* *} \\
(2.26)\end{array}$ & \\
\hline CHINA & & $\begin{array}{l}109.131 \text { *** } \\
(2.67)\end{array}$ & & $\begin{array}{l}104.665^{\text {**** }} \\
(2.78)\end{array}$ \\
\hline MR30 & $\begin{array}{l}3.049 * \\
(1.79)\end{array}$ & $\begin{array}{l}2.910 \\
(1.61)\end{array}$ & & \\
\hline DAY30 & $\begin{array}{l}-1.236 \\
(-1.33)\end{array}$ & $\begin{array}{l}-1.313 \\
(-1.47)\end{array}$ & & \\
\hline MR60 & & & $\begin{array}{l}2.574 * * * \\
(3.10)\end{array}$ & $\begin{array}{l}2.542 * * * \\
(2.95)\end{array}$ \\
\hline DAY60 & & & $\begin{array}{l}-1.062 * \\
(-2.00)\end{array}$ & $\begin{array}{c}-0.994 * \\
(-1.86)\end{array}$ \\
\hline Constant & $\begin{array}{l}261.959^{* * *} \\
(2.90)\end{array}$ & $\begin{array}{l}165.063 \\
(1.47)\end{array}$ & $\begin{array}{l}303.102 * * * \\
(3.04)\end{array}$ & $\begin{array}{l}203.061 * \\
(1.71)\end{array}$ \\
\hline Observations & 70 & 70 & 70 & 70 \\
\hline Adj R-squared & 0.567 & 0.592 & 0.619 & 0.645 \\
\hline
\end{tabular}

Description: Description: Ordinary Least squares estimation for a cross-section of Chinese real estate IPOs that have taken place between 1992 and 2013. Group A regressions controls for the 30-day market return and IPO numbers prior the IPO while group B regressions controls for the 60 -day variables. INIRE is the initial return of a company's IPO which is a common measure of IPO underpricing. UEO is the weighted average of urban economic openness which is the sum of city-level imports and exports as share of this city's GDP. The land-use right that a company owns in one city as a share of its overall land-use right is used as the weight. $L N L A G$ is the natural logarithm of the time lag between issuing and listing dates. LNPRO is the natural logarithm of the IPO proceeds. ROREA is the return on real estate assets of a company. LNAGE is the natural logarithm of the firm age for which it has been running as a real estate company before the IPO. STATEO is equal to 1 if the company is state-owned, 0 otherwise. CHINA is equal to 1 of the company is listed in Mainland China, 0 otherwise. MR30 and MR60 are 30- and 60-day market returns prior to the IPO. DAY30 and DAY60 are the numbers of IPOs in which have taken place 30 or 60 days prior to the IPO respectively. tstatistics are in the parentheses. $* * *, * *, *$ denote significance at $1 \%, 5 \%$ or $10 \%$ respectively.

reach the listing after the offering, the more uncertainty and the higher IPO underpricing we expect. As the time lag is log-transformed, holding other explanatory variables constant, the expected return difference of an IPO between two periods in time $\left(t_{1}, t_{2}\right)$ is represented as follows: 


$$
\operatorname{INIRE}_{i, 1}-\operatorname{INIRE}_{i, 2}=\beta_{L N L A G} \times\left[\ln \left(t_{1}\right)-\ln \left(t_{2}\right)\right]=\beta_{L N L A G} \times \ln \left(\frac{t_{1}}{t_{2}}\right)
$$

From Eq. (5) it becomes clear that the relative change of the time lag affects the initial returns regardless of the baseline of time. If $\beta_{L N L A G A}$ is equal to 44.573 as shown in specification A1, then a $10 \%$ increase in the time gap between the issuance and the listing (around 4 days considering the average time of 37 days - see Table 1) will result in a $4.25 \%$ increase in the underpricing.

Another significant determinant is the firm size, which serves as a proxy for the degree of asymmetric information associated with the IPO. Unlike some of the previous Chinese IPO studies, the results in this study are in line with the information asymmetry theory: the larger the firm, the smaller the uncertainty is and therefore the lower the underpricing is. The coefficients on $L N P R O$ are significant throughout all regressions at $95 \%$ or $90 \%$ confidence level. In specification A1, a $10 \%$ increase in the proceeds leads to a $4.37 \%$ decrease in IPO underpricing. Interestingly, we find that the return on real estate assets (ROREA) positively affects the IPO underpricing at $10 \%$ level (see specification A1 and A2), with a $2.79 \%$ to $2.99 \%$ increase in the IPO initial returns when ROREA increases by $10 \%$. In fact, when the return on real estate assets of an IPO company is relatively high, investors read this information as a signal of "good" firm quality and hence they are more willing to participate in the IPO with a higher after-market bidding price.

Contrary to previous research in developed countries, we also find no significant relationship between the firm age and the underpricing, further indicating that the classic information asymmetry theory may be weakened by the more "immature" Chinese market. Models A1 and B1 include state ownership (STATEO) and control for 30-day and 60-day pre-IPO market conditions respectively. The coefficients for state ownership are both significant and positive suggesting that state-owned companies experience significantly higher IPO underpricing than private companies. This is consistent with the majority of Chinese IPO studies, which blame the extremely high underpricing on the political connections and government interventions - see Tian (2011). For example, Chan et al. (2004) find that the state ownership, including government and legal entity ownership, is positively related to IPO underpricing. Chang et al. (2008) argue that the Chinese government decides the IPO supply and sets the price-to-income limit for offering shares, with both regulations leading to a high level of underpricing. With regards to post-IPO stock returns, Fan et al. (2007) show that companies with more political connections actually underperform those which are loosely connected. Specifications A2 and B2 include the IPO location (China) instead of state ownership status and coefficients are significantly positive, consistent with Wong et al. (2013), where listing in Mainland China (i.e. market less transparent) leads to a greater underpricing.

To include the market factors proposed by Loughran and Ritter's (2002) and account for market euphoria, most studies control for market returns during the 30 days preceding the IPO. As we argue that a longer momentum effect could exist for Chinese companies, ${ }^{7}$ we also control for 60-day market returns as a robustness check. Group A and $\mathrm{B}$ regressions include market returns and number of IPOs issued during respectively 30 and 60 days before the IPO. Consistent with Loughran and Ritter's (2002)

\footnotetext{
${ }^{7}$ If the market is less efficient, the time the investors need to adjust their apriori assumptions is longer.
} 
prospect theory, we find that investors' sentiment (proxied by market returns) positively affects the IPO initial returns. When we pass from a 30- to 60-day period, the coefficient becomes more significant (99\% in model B1 from $90 \%$ in model A1) and hence we find support for our assumption about the weak efficiency of Chinese markets. The number of IPOs during the period preceding the IPO listing date shows a negative effect on IPO underpricing for both periods (30 and 60 days), but the coefficient is only significant when 60 days are used, supporting Alt1 (2005) who argues that the unknown common factor about IPO valuation will be revealed by previous IPOs, resulting in less underpricing.

Furthermore, consistent with Wong et al. (2013), we find a significant impact of listing location on IPO initial returns. Companies listed in Mainland China experience significantly higher IPO underpricing than those listed in Hong Kong or Singapore. Wong et al. (2013) argue that the low underpricing is a form of reward to a company choosing to go public in a more competitive and informationally transparent market and it signals a high firm quality. One may argue that the characteristics of companies listed in Mainland China $(a)$ are systematically different from those listed outside $(b)$. The same argument may be applied to the ownership structure of state-owned $(a)$ versus private $(b)$ companies. Hence, we investigate the need to estimate separate models by using a Chow test. Firstly, we split the sample by IPO location or state ownership, and estimate the two following regressions:

$$
\begin{gathered}
\operatorname{INIRE}_{i, a}=\beta_{0, a}+\beta_{U E O, a} \times U E O_{i, a}+\beta_{i, a} \times X_{i, a}+\varepsilon_{i, a} \text { if } \frac{\text { CHINA }}{\text { STATEO }}=1 \\
\operatorname{INIRE}_{i, b}=\beta_{0, b}+\beta_{U E O, b} \times U E O_{i, b}+\beta_{i, b} \times X_{i, b}+\varepsilon_{i, b} \text { if } \frac{\text { CHINA }}{\text { STATEO }} \neq 1
\end{gathered}
$$

Secondly, we compare these results with the ones obtained estimating the pooled model from Eq. (5) which assumes that the coefficients are the same across the two groups. The Chow statistic is the output of an F-Test comparing the difference between the above coefficients:

$$
F=\frac{R S S_{\text {pooled }}-\left(R S S_{a}+R S S_{b}\right)}{R S S_{a}+R S S_{b}} \times \frac{n-2 k}{k} \sim F(k, n-2 k)
$$

where $R S S=\sum_{i}^{N} \varepsilon_{i}^{2}$ is the residual sum of the squares, i.e. the variation unexplained by the regression model. ${ }^{8}$ Results reported in Panel A of Table 3 indicate that we can estimate the pooled sample in both cases.

\section{Two Stage Least Square (2SLS) Estimation}

Since $U E O$ is a company-level variable constructed by using macroeconomic factors (trade openness of Chinese cities), we need to guarantee that it is not

\footnotetext{
${ }^{8}$ If the difference in the combined residual sum of the squares of the two separate models and the residual sum of the squares of the pooled model is significant, we then should consider estimating the model separately by IPO location.
} 
Table 3 Chow test for the state ownership vs IPO location and variance inflation factors

\begin{tabular}{|c|c|c|c|c|}
\hline & $\mathbf{A 1}$ & $\mathbf{A 2}$ & B1 & B2 \\
\hline \multicolumn{5}{|c|}{ Panel A: Chow Test } \\
\hline \multicolumn{5}{|l|}{ Prob $>$ F } \\
\hline STATEO & 0.5724 & & 0.4046 & \\
\hline CHINA & & 0.9239 & & 0.3117 \\
\hline \multicolumn{5}{|c|}{ Panel B: Variance Inflation Factors (VIF) } \\
\hline$U E O$ & 1.25 & 1.27 & 1.25 & 1.27 \\
\hline$L N L A G$ & 1.15 & 1.09 & 1.15 & 1.10 \\
\hline$L N P R O$ & 1.56 & 1.98 & 1.55 & 1.94 \\
\hline ROREA & 1.10 & 1.10 & 1.11 & 1.11 \\
\hline$L N A G E$ & 1.31 & 1.31 & 1.31 & 1.30 \\
\hline STATEO & 1.71 & & 1.67 & \\
\hline CHINA & & 1.98 & & 1.98 \\
\hline MR30 & 1.07 & 1.07 & & \\
\hline DAY3O & 1.28 & 1.23 & & \\
\hline MR60 & & & 1.07 & 1.06 \\
\hline DAY60 & & & 1.27 & 1.25 \\
\hline Mean VIF & 1.30 & 1.38 & 1.30 & 1.38 \\
\hline
\end{tabular}

correlated with unobserved economic factors which might also affect the individual IPO performance. In fact, if $U E O$ is correlated with the error term $\varepsilon$ in Eq. (5), the exogeneity assumption of OLS estimators is violated and we are presented with an omitted variable bias. As a result, the OLS estimation would be inconsistent with

$$
E[\beta \mid X]=\beta+X^{\prime} X^{-1} X^{\prime} \varepsilon \neq \beta
$$

A common method to correct for endogeneity is the use of instrumental variables (IVs) which are correlated with the endogenous variable (UEO in our case) but uncorrelated with the error term $\varepsilon$. Previous studies find a significant relationship between the exchange rate volatility and foreign trade volumes. However, Gu and Gao (2007) find that the exchange rate volatility does not significantly affect foreign trade volume in China because, being a developing country, trades may be mainly driven by domestic demand. Hence we expect disposable household income to have a positive relationship with trade volumes and to be unlikely related with IPO returns. Therefore we use the natural logarithm of disposable household income per capita $(L N D I N C)$ as an instrument for $U E O$ in our estimation. As a robustness check (see details in the following robustness check section), we also use an alternative instrument (distance between a city and its closest port) and find that results do not change.

The regional disposable household income per capita is collected from the City Annual Statistical Reports. We use a two stage least square estimation (2SLS). In the 
first stage, we estimate the predictions of the endogenous variable $U E O$ by using the instrumental variable:

$$
U E O=\delta_{0}+\delta_{1} x_{1}+\ldots+\delta_{k-1} x_{k-1}+\theta L N D I N C+v_{U E O}
$$

In the second stage, the fitted values of $U E O$ are used to replace the actual regressor and we estimate the following model:

$$
\operatorname{INIRE}=\alpha_{0}+\alpha_{1}+\ldots+\alpha_{k-1} x_{k-1}+\lambda L N D I N C+\eta
$$

where $\eta=\varepsilon+\beta_{U E O} v_{U E O}, a_{j}=\beta_{j}+\beta_{U E O} \delta_{j}$ and $\lambda=\beta_{U E O} \theta$.

Results in Table 4 show that the effect of UEO on IPO initial returns remains negative and significant throughout the estimations, with significance levels reduced to $90 \%$. A $10 \%$ increase in UEO leads to a decrease between $10.50 \%$ and $20.40 \%$ in IPO underpricing. As expected, the efficiency in a 2SLS specification is reduced while standard errors are not significantly different from OLS models. The effect of the time lag remains positive and strongly significant and the 60-day pre-IPO market performance is still preferred to a 30-day market return.

Durbin and Wu-Hausman estimates which include the estimated error term from the first stage in the 2SLS estimation as an additional variable are performed to test for the endogeneity of $U E O$. Under the null hypothesis that all the variables are exogenous, the coefficients on the error term from the first stage should be insignificant in the Durbin and Wu-Hausman tests (otherwise, we should reject the null hypothesis and treat $U E O$ as endogenous). The Durbin and $\mathrm{Wu}$-Hausman tests are performed for each 2SLS regression and statistics are reported at the bottom of Table 4. Apart from the Wu-Hausman statistic in regression D2 (with IPO location and 60-day market variables), all other statistics suggest that we need to treat $U E O$ as endogenous.

As there is no clear definition or test for the weakness of an instrument, we at least report the results of our first-stage regression (Table 5), where the statistical significance of the instrumental variable used to explain the endogenous variable $U E O$ is reported. The positive relationship between disposable household income per capita and UEO is significant throughout the four specifications; the R-squared is between 0.24 and 0.29 while the $F$ statistic ranges from 3.25 to 6.56 The $F$-test strongly relies on the number of endogenous variables and the number of instruments so that the more additional valid instruments are used, the greater the $F$ statistic of the joint significance of the instruments will be. Overall, our results suggest that the chosen instrument is appropriate for our model.

\section{Further Tests and Robustness Checks}

\section{Multicollinearity}

In cross-sectional studies, variance inflation factors (VIF) are usually calculated to test for the presence of multicollinearity which could lead to biased estimators. We report 
Table 4 Two stage least square estimation of IPO initial returns

\begin{tabular}{|c|c|c|c|c|}
\hline Model: & $\mathrm{C} 1$ & $\mathrm{C} 2$ & D1 & $\mathrm{D} 2$ \\
\hline$U E O$ & $\begin{array}{l}-2.040^{*} \\
(-1.75)\end{array}$ & $\begin{array}{l}-1.217^{* *} \\
(-2.05)\end{array}$ & $\begin{array}{l}-1.792 * \\
(-1.72)\end{array}$ & $\begin{array}{l}-1.050 * \\
(-1.90)\end{array}$ \\
\hline$L N L A G$ & $\begin{array}{l}54.500 * * * \\
(2.80)\end{array}$ & $\begin{array}{l}55.895^{* * * *} \\
(4.21)\end{array}$ & $\begin{array}{l}46.675 * * * \\
(2.60)\end{array}$ & $\begin{array}{l}46.922 * * * \\
(3.79)\end{array}$ \\
\hline LNPRO & $\begin{array}{l}-24.480 \\
(-1.09)\end{array}$ & $\begin{array}{l}-19.456 \\
(-1.15)\end{array}$ & $\begin{array}{l}-26.855 \\
(-1.37)\end{array}$ & $\begin{array}{l}-22.228 \\
(-1.49)\end{array}$ \\
\hline ROREA & $\begin{array}{l}0.244 \\
(1.14)\end{array}$ & $\begin{array}{l}0.242 \\
(1.62)\end{array}$ & $\begin{array}{l}0.212 \\
(1.12)\end{array}$ & $\begin{array}{l}0.212 \\
(1.59)\end{array}$ \\
\hline$L N A G E$ & $\begin{array}{l}-95.460 \\
(-1.37)\end{array}$ & $\begin{array}{l}-57.441 \\
(-1.39)\end{array}$ & $\begin{array}{l}-84.495 \\
(-1.37)\end{array}$ & $\begin{array}{l}-50.399 \\
(-1.34)\end{array}$ \\
\hline STATEO & $\begin{array}{l}141.700 * * \\
(2.06)\end{array}$ & & $\begin{array}{l}126.483^{* *} \\
(2.07)\end{array}$ & \\
\hline CHINA & & $\begin{array}{l}153.207 * * * \\
(3.07)\end{array}$ & & $\begin{array}{l}138.356^{* * * *} \\
(3.12)\end{array}$ \\
\hline$M R 30$ & $\begin{array}{l}1.399 \\
(0.18)\end{array}$ & $\begin{array}{l}2.020 \\
(1.58)\end{array}$ & & \\
\hline$D A Y 30$ & $\begin{array}{l}-3.986 \\
(-1.55)\end{array}$ & $\begin{array}{l}-2.732 * \\
(-1.75)\end{array}$ & & \\
\hline MR60 & & & $\begin{array}{l}1.896^{*} \\
(1.83)\end{array}$ & $\begin{array}{l}2.213 * * * \\
(3.17)\end{array}$ \\
\hline DAY60 & & & $\begin{array}{l}-2.355 * \\
(-1.92)\end{array}$ & $\begin{array}{l}-1.611 * * \\
(-2.13)\end{array}$ \\
\hline Constant & $\begin{array}{l}472.800 * * \\
(2.30)\end{array}$ & $\begin{array}{l}232.299 * \\
(1.81)\end{array}$ & $\begin{array}{l}481.101 * * * \\
(2.65)\end{array}$ & $\begin{array}{l}259.749 * * \\
(2.23)\end{array}$ \\
\hline Durbin (score) chi2(1) & $\begin{array}{l}7.2886 \\
(p=0.0069)\end{array}$ & $\begin{array}{l}4.0682 \\
(p=0.0437)\end{array}$ & $\begin{array}{l}5.8687 \\
(p=0.0154)\end{array}$ & $\begin{array}{l}2.7783 \\
(p=0.0956)\end{array}$ \\
\hline Wu-Hausman F(1,60) & $\begin{array}{l}6.9735 \\
(p=0.0105)\end{array}$ & $\begin{array}{l}3.7022 \\
(p=0.0591)\end{array}$ & $\begin{array}{l}5.4907 \\
(p=0.0225)\end{array}$ & $\begin{array}{l}2.4798 \\
(p=0.1206)\end{array}$ \\
\hline
\end{tabular}

Description: 2SLS estimation with one instrument, where group C regressions control for the 30-day market return and 30-day IPO numbers prior to the IPO while group D regressions control for the 60-day variables. INIRE is the initial return of a company's IPO which is a common measure of IPO underpricing. UEO is the weighted average of urban economic openness which is the city-level imports and exports as share of this city's GDP. The land-use right that a company owns in one city as a share of its overall land-use right is used as the weight. The instrumental variable for the $U E O$ is the natural logarithm of the disposable household income per capita $(L N D I N C)$. LNLAG is the natural logarithm of the time lag between issuing and listing dates. $L N P R O$ is the natural logarithm of the IPO proceeds. ROREA is the return on real estate assets of a company. $L N A G E$ is the natural logarithm of the firm age for which it has been running as a real estate company before the IPO. STATEO is equal to 1 if the company is state-owned, 0 otherwise. CHINA is equal to 1 of the company is listed in Mainland China, 0 otherwise. MR30 and MR60 are 30- and 60-day market return before the IPO. DAY30 and DAY60 are the IPO numbers in 30 and 60 days prior IPO respectively. $\mathrm{z}$-statistics are in the parentheses for 2 SLS regressions. $* * *, * * *$ denote significance at $1 \%, 5 \%$ or $10 \%$ respectively. 
Table 5 First-stage regression for urban economic openness

\begin{tabular}{lllll}
\hline Model: & $\mathrm{C} 1$ & $\mathrm{C} 2$ & $\mathrm{D} 1$ & $\mathrm{D} 2$ \\
\hline LNDINC Coef. & 44.7867 & 67.0882 & 44.3146 & 64.3094 \\
P-value & 0.076 & 0.013 & 0.08 & 0.018 \\
R-squared & 0.2408 & 0.2917 & 0.2400 & 0.2798 \\
F test & 3.2474 & 6.5615 & 3.1755 & 5.9370 \\
Prob $>F$ & 0.0765 & 0.0129 & 0.0797 & 0.0178 \\
\hline
\end{tabular}

the VIFs of our estimations in Panel B of Table 3. Following Chatterjee and Hadi (2006), ${ }^{9}$ since no VIF is larger than 10 and their average is not considerably larger than 1 , we conclude that our estimation is not significantly affected by multicollinearity.

\section{Urban Economic Openness Vs. Economic Growth}

As economic variables are usually highly correlated with each other, there may be concerns that the significant impact of UEO is actually associated with economic factors other than regional foreign trade openness (e.g. one might argue that UEO is higher in regions with a high GDP). Therefore, we control for the effect of the wider economy to determine whether foreign trade openness rather than the overall economic performance affects IPO underpricing. China is a developing country that has maintained a high speed of economic growth for the last three decades and the difference in the GDP growth across regions and time is very small. Therefore we use GDP levels instead of growth rates as they potentially capture other effects such as the size of the region or the developing speed. Since regional GDP levels also include foreign trade volumes, we deduct the net exports from the local GDP to exclude the foreign trade contribution and take the natural logarithm form of it $(L N N G D P)$. Once we obtain this measure at the city level, we then compute a weighted average to obtain the measure at company level following the same procedure used for UEO. As state ownership (STATEO) and IPO location (CHINA) can be considered alternative proxies and show similar results, in this part of robustness checks we only report results including state ownership.

Firstly, we use $L N N G D P$ instead of $U E O$ in the OLS regressions to estimate the impact of net regional GDP on IPO underpricing (columns E1 and E2), with Group 1 and 2 controlling for 30- and 60-day market variables respectively. Table 6 shows that, supporting our expectation, the coefficients of $L N N G P$ are negative but no significant relationship is found between $L N N G D P$ and IPO initial returns - and all other coefficients do not change significantly. As $L N N G D P$ excludes foreign trades, the correlation with $U E O$ is low $(0.11)$ and hence we therefore estimate an OLS model including both $U E O$ and $L N N G D P$ (F1 and F2). Coefficients and statistical significance of $U E O$ are similar to the ones obtained in the baseline regressions (A1 and $\mathrm{B} 1$ ) and the net GDP is still not significant. This finding confirms that regional trade openness

\footnotetext{
${ }^{9}$ They show that multicollinearity exists when there are VIFs larger than 10 and the average of all VIFs is larger than 1 but nowhere near that threshold. The majority of the literature also argues that collinearity only starts to become an issue when there is a VIF larger than 30 .
} 
Table 6 Estimation models controlling for economic activities

\begin{tabular}{|c|c|c|c|c|c|c|}
\hline & \multicolumn{4}{|l|}{ OLS } & \multicolumn{2}{|l|}{ 2SLS } \\
\hline & E1 & E2 & F1 & F2 & G1 & G2 \\
\hline$U E O$ & & & $\begin{array}{l}-0.256^{* *} \\
(-2.02)\end{array}$ & $\begin{array}{l}-0.273^{* *} \\
(-2.14)\end{array}$ & $\begin{array}{l}-1.815^{* *} \\
(-2.05)\end{array}$ & $\begin{array}{l}-1.534 * * \\
(-2.03)\end{array}$ \\
\hline$L N N G D P$ & $\begin{array}{l}-8.754 \\
(-0.62)\end{array}$ & $\begin{array}{l}-8.856 \\
(-0.67)\end{array}$ & $\begin{array}{l}-8.618 \\
(-0.62)\end{array}$ & $\begin{array}{l}-8.827 \\
(-0.67)\end{array}$ & $\begin{array}{l}-7.791 \\
(-0.36)\end{array}$ & $\begin{array}{l}-8.695 \\
(-0.47)\end{array}$ \\
\hline$L N L A G$ & $\begin{array}{l}41.985^{* *} \\
(2.50)\end{array}$ & $\begin{array}{l}32.127^{* *} \\
(2.40)\end{array}$ & $\begin{array}{l}43.426^{* *} \\
(2.61)\end{array}$ & $\begin{array}{l}34.167^{* *} \\
(2.59)\end{array}$ & $\begin{array}{l}52.220 * * * \\
(2.92)\end{array}$ & $\begin{array}{l}43.588^{* * * *} \\
(2.76)\end{array}$ \\
\hline LNPRO & $\begin{array}{l}-45.385^{* *} \\
(-2.32)\end{array}$ & $\begin{array}{l}-44.179^{* * *} \\
(-2.37)\end{array}$ & $\begin{array}{l}-42.373^{* *} \\
(-2.29)\end{array}$ & $\begin{array}{l}-41.003^{* *} \\
(-2.38)\end{array}$ & $\begin{array}{l}-24.010 \\
(-1.14)\end{array}$ & $\begin{array}{l}-26.329 \\
(-1.46)\end{array}$ \\
\hline ROREA & $\begin{array}{l}0.301 * \\
(1.72)\end{array}$ & $\begin{array}{l}0.267 \\
(1.38)\end{array}$ & $\begin{array}{l}0.293 \\
(1.63)\end{array}$ & $\begin{array}{l}0.258 \\
(1.28)\end{array}$ & $\begin{array}{l}0.245 \\
(1.25)\end{array}$ & $\begin{array}{l}0.215 \\
(1.27)\end{array}$ \\
\hline$L N A G E$ & $\begin{array}{l}-1.655 \\
(-0.06)\end{array}$ & $\begin{array}{l}-2.086 \\
(-0.07)\end{array}$ & $\begin{array}{l}-13.309 \\
(-0.46)\end{array}$ & $\begin{array}{l}-14.504 \\
(-0.52)\end{array}$ & $\begin{array}{l}-84.380 \\
(-1.46)\end{array}$ & $\begin{array}{l}-71.862 \\
(-1.45)\end{array}$ \\
\hline STATEO & $\begin{array}{l}67.759 * * \\
(2.15)\end{array}$ & $\begin{array}{l}59.415^{*} \\
(1.87)\end{array}$ & $\begin{array}{l}76.786^{* *} \\
(2.49)\end{array}$ & $\begin{array}{l}69.270 * * \\
(2.26)\end{array}$ & $\begin{array}{l}131.800 * * \\
(2.20)\end{array}$ & $\begin{array}{l}114.790 * * \\
(2.23)\end{array}$ \\
\hline MR30 & $\begin{array}{l}3.287 * \\
(1.79)\end{array}$ & & $\begin{array}{l}3.050 * \\
(1.77)\end{array}$ & & $\begin{array}{l}1.608 \\
(0.94)\end{array}$ & \\
\hline DAY3O & $\begin{array}{l}-0.785 \\
(-0.90)\end{array}$ & & $\begin{array}{l}-1.180 \\
(-1.28)\end{array}$ & & $\begin{array}{l}-3.590^{*} \\
(-1.65)\end{array}$ & \\
\hline MR60 & & $\begin{array}{l}2.697 * * * \\
(2.97)\end{array}$ & & $\begin{array}{l}2.575 * * * \\
(3.05)\end{array}$ & & $\begin{array}{l}2.012 * * \\
(2.24)\end{array}$ \\
\hline DAY60 & & $\begin{array}{l}-0.810^{*} \\
(-1.67)\end{array}$ & & $\begin{array}{l}-1.043^{*} \\
(-1.95)\end{array}$ & & $\begin{array}{l}-2.117 * * \\
(-2.11)\end{array}$ \\
\hline Constant & $\begin{array}{l}256.791 * * * \\
(2.66)\end{array}$ & $\begin{array}{l}296.962 * * * \\
(2.91)\end{array}$ & $\begin{array}{l}286.636^{* * * *} \\
(2.77)\end{array}$ & $\begin{array}{l}328.893 * * * \\
(2.93)\end{array}$ & $\begin{array}{l}468.600 * * \\
(2.54)\end{array}$ & $\begin{array}{l}476.381 \text { *** } \\
(2.99)\end{array}$ \\
\hline Adj R-squared & 0.552 & 0.601 & 0.562 & 0.615 & & \\
\hline
\end{tabular}

Description: OLS regressions are using state-ownership (STATEO), including 30- and 60-day market variables respectively. $L N N G D P$ is the city-level net GDP calculated as a city's GDP excludes the (Exports - Imports), weighted by the land-use right that a company owns in one city as a share of its overall land-use right. INIRE is the initial return of a company's IPO which is a common measure of IPO underpricing. UEO is the weighted average of urban economic openness which is the sum of city-level imports and exports as share of this city's GDP. The land-use right that a company owns in one city as a share of its overall land-use right is used as the weight. $L N L A G$ is the natural logarithm of the time lag between issuing and listing dates. $L N P R O$ is the natural logarithm of the IPO proceeds. ROREA is the return on real estate assets of a company. LNAGE is the natural logarithm of the firm age for which it has been running as a real estate company before the IPO. STATEO is equal to 1 if the company is state-owned, 0 otherwise. MR30 and MR60 are 30- and 60-day market return before the IPO. DAY30 and DAY60 are the IPO numbers in 30 and 60 days prior IPO respectively. t-statistics are in the parentheses for OLS regressions and z-statistics are in the parentheses for 2SLS regressions. ***, **, * denote significance at $1 \%, 5 \%$ or $10 \%$ respectively.

rather than the wider economy affects IPO underpricing of Chinese real estate companies. Finally, we estimate a 2SLS model controlling for $L N N G D P$. Compared to baseline models (C1 and D1), results hold. The economic effect of UEO is even stronger and the efficiency is improved (95\% confidence level in both models G1 
and G2). Finally, we find no significant effect of $L N N G D P$ on IPO initial returns, which further supports the robustness of our results.

\section{Market Changes and Time Dummies}

Our study includes real estate IPOs from 1992 to 2013. This has been a dynamic period during which the Chinese market has undergone several stock market reforms. Therefore, it is reasonable to consider whether the relationship between UEO and real estate IPO underpricing has changed due to those changes and whether our results remain robust. To control for the general changes in the Chinese market, we create four time dummies, each covering a five-year period (results in Table 7). With this approach, we only use four additional variables instead of 21 year dummies and this allows us to save degrees of freedom - very important considering the sample size. This approach also seems reasonable because macroeconomic variables already reflect time variation and hence changes in the market dynamic.

Comparing our baseline results (Table 2) with the ones in Table 7, we do not find significant differences. UEO coefficients remain negative and significant at $95 \%$ confidence level, while the scale of the effect increases by $20 \%$ and $8 \%$ when controlling respectively for 30- and 60-day market performance. The effect of the time lag between issuing and listing dates remains positive, while the significance is reduced. $L N P R O$ does not significantly affect IPO underpricing any longer and this is inconsistent with the information asymmetry theory. This supports the main argument of the presence of a distortion in the application of classic theories to the Chinese market.

\section{SLS Model with Two Instruments}

One limitation of using 2SLS estimation relates to the quality of instruments used in the first stage. By using disposable household income per capita, we have a just-identified case and therefore we cannot test for the exogeneity of the instrument, a key assumption of the 2SLS estimation. As an alternative measure to instrument for $U E O$, we estimate the distance of each city to the nearest port following Wang et al. (2011). As part of the policy started in 1979 to aim at a more globalised Chinese market, the government has agreed on fourteen coastal cities to become major ports (e.g. Shanghai, Guangzhou, Dalian). Therefore, the distance to the nearest major port can be seen as a valid instrument for the city's trade openness. In our sample we observe that about $50 \%$ of the companies have businesses in more than one city. Therefore, we follow the same procedure used for $U E O$ and $L N N G D P$ to compute the weighted average of the distances for every company. Results of the over-identified 2SLS estimation using the disposable household income per capita and the distance of the city to its nearest major port are reported in Table 8 .

The effect of UEO on IPO underpricing remains negative and significant, with coefficient decreasing while statistical significance increasing. The negative results on proceeds are now consistent with the classic theory that the larger the firm is, the smaller the uncertainty and therefore the smaller the underpricing of the firm is. As an operating performance measurement, investors see the return on real estate assets as a reflection of a real estate company's earning ability and they are more willing to pay 
Table 7 Estimation models controlling for time dummies

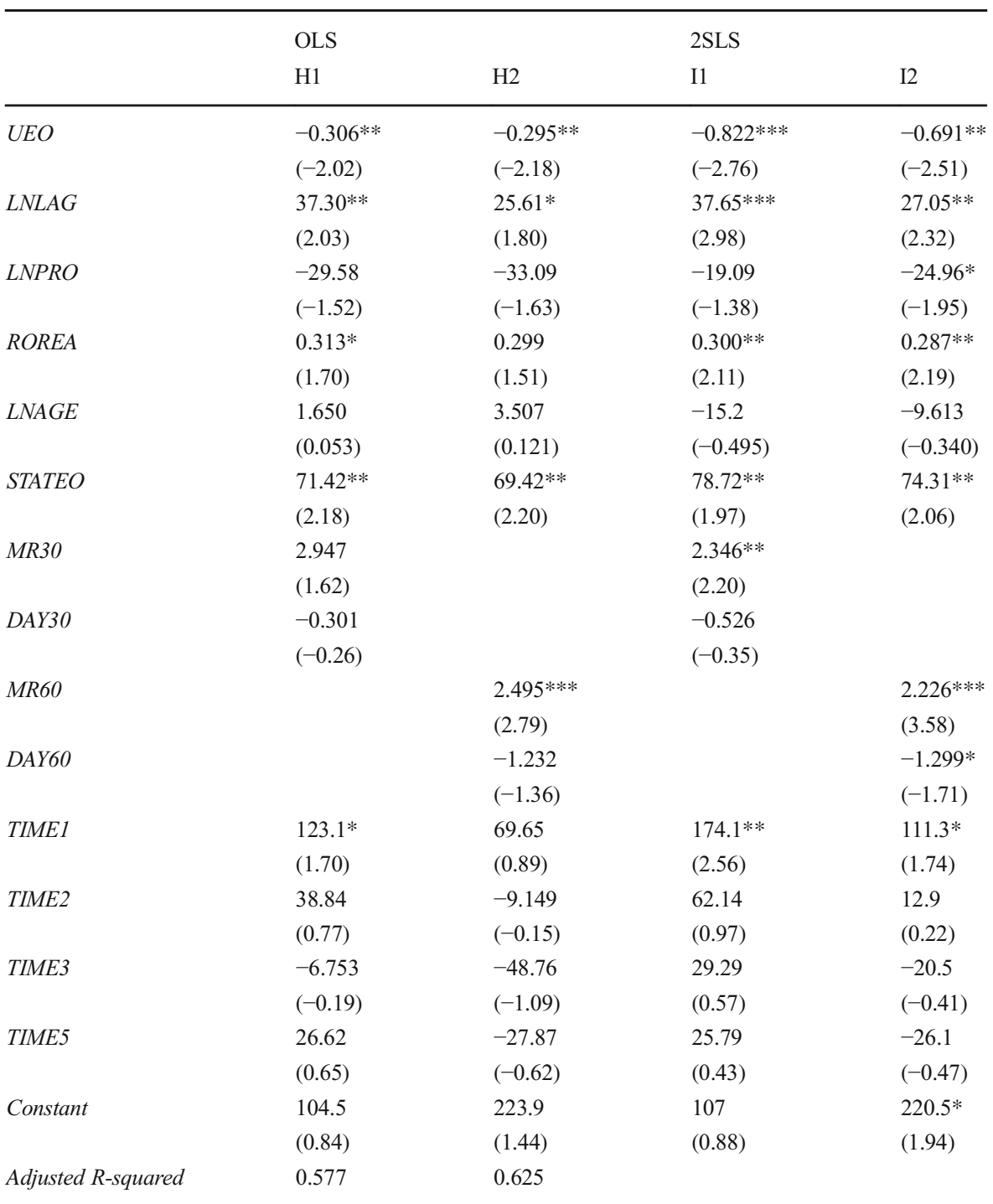

Description: OLS regressions are using state-ownership (STATEO), including 30-day and 60-day market variables respectively. All the regressions in Table 7 control for time dummies. One time dummy was created to cover every five year. Five dummies are created while one was omitted in the regression due to collinearity. INIRE is the initial return of a company's IPO which is a common measure of IPO underpricing. UEO is the weighted average of the urban economic openness which is the sum of the city-level imports and exports as a share of this city's GDP. The land-use right that a company owns in one city as a share of its overall land-use right is used as the weight. $L N L A G$ is the natural logarithm of the time lag between issuing and listing dates. $\angle N P R O$ is the natural logarithm of the IPO proceeds. ROREA is the return on real estate assets of a company. $L N A G E$ is the natural logarithm of the firm age for which it has been running as a real estate company before the IPO. STATEO is equal to 1 if the company is state-owned, 0 otherwise. MR30 and MR60 are 30- and 60day market return before the IPO. DAY30 and DAY60 are the IPO numbers in 30 and 60 days prior to IPO respectively. t-statistics are in the parentheses for OLS regressions and z-statistics are in the parentheses for 2SLS regressions. $* * * * *, *$ denote significance at $1 \%, 5 \%$ or $10 \%$ respectively 
Table 8 Two stage least square estimation with two instruments

\begin{tabular}{|c|c|c|c|c|}
\hline Model: & $\mathrm{J} 1$ & $\mathrm{~J} 2$ & $\mathrm{~K} 1$ & $\mathrm{~K} 2$ \\
\hline$U E O$ & $\begin{array}{l}-0.756^{* *} \\
(-0.35)\end{array}$ & $\begin{array}{l}-0.706^{* *} \\
(-0.31)\end{array}$ & $\begin{array}{l}-0.888^{* *} \\
(-0.34)\end{array}$ & $\begin{array}{l}-0.799 * * * \\
(-0.30)\end{array}$ \\
\hline$L N L A G$ & $\begin{array}{l}47.36^{* * * *} \\
(11.66)\end{array}$ & $\begin{array}{l}52.10^{* * * *} \\
(10.85)\end{array}$ & $\begin{array}{l}39.94 * * * \\
(11.55)\end{array}$ & $\begin{array}{l}44.50 \text { *** } \\
(10.63)\end{array}$ \\
\hline LNPRO & $\begin{array}{l}-39.87 * * * \\
(-11.74)\end{array}$ & $\begin{array}{l}-27.98 * * \\
(-12.73)\end{array}$ & $\begin{array}{l}-37.41 * * * \\
(-11.45)\end{array}$ & $\begin{array}{l}-26.15 * * \\
(-12.09)\end{array}$ \\
\hline ROREA & $\begin{array}{l}0.284 * * \\
(0.132)\end{array}$ & $\begin{array}{l}0.262 * * \\
(0.125)\end{array}$ & $\begin{array}{l}0.243^{*} \\
(0.130)\end{array}$ & $\begin{array}{l}0.222 * \\
(0.121)\end{array}$ \\
\hline$L N A G E$ & $\begin{array}{l}-37.04 \\
(-32.30)\end{array}$ & $\begin{array}{l}-34.27 \\
(-30.14)\end{array}$ & $\begin{array}{l}-43.4 \\
(-31.69)\end{array}$ & $\begin{array}{l}-39.04 \\
(-29.04)\end{array}$ \\
\hline STATEO & $\begin{array}{l}96.54 * * * \\
(36.80)\end{array}$ & & $\begin{array}{l}93.89 * * * \\
(35.81)\end{array}$ & \\
\hline CHINA & & $\begin{array}{l}128.7 * * * \\
(37.75)\end{array}$ & & $\begin{array}{l}126.9 * * * \\
(36.15)\end{array}$ \\
\hline$M R 30$ & $\begin{array}{l}2.587 * * \\
(1.071)\end{array}$ & $\begin{array}{l}2.515^{* *} \\
(1.017)\end{array}$ & & \\
\hline$D A Y 30$ & $\begin{array}{l}-2.006 \\
(-1.275)\end{array}$ & $\begin{array}{l}-1.942 * \\
(-1.174)\end{array}$ & & \\
\hline MR60 & & & $\begin{array}{l}2.299 * * * \\
(0.66)\end{array}$ & $\begin{array}{l}2.325 \text { *** } \\
(0.61)\end{array}$ \\
\hline DAY60 & & & $\begin{array}{l}-1.585^{* *} \\
(-0.66)\end{array}$ & $\begin{array}{l}-1.402 \text { ** } \\
(-0.61)\end{array}$ \\
\hline Constant & $\begin{array}{l}321.1 * * * \\
(103.8)\end{array}$ & $\begin{array}{l}194.9 * \\
(104.6)\end{array}$ & $\begin{array}{l}375.1 * * * \\
(102.2)\end{array}$ & $\begin{array}{l}240.5^{* *} \\
(101.9)\end{array}$ \\
\hline Durbin (score) chi2(1) & $\begin{array}{l}2.9280 \\
(p=0.0817)\end{array}$ & $\begin{array}{l}2.5001 \\
(p=0.1138)\end{array}$ & $\begin{array}{l}5.0492 \\
(p=0.0246)\end{array}$ & $\begin{array}{l}4.0607 \\
(p=0.0439)\end{array}$ \\
\hline Wu-Hausman $F(1,60)$ & $\begin{array}{l}2.61930 \\
(p=0.1108)\end{array}$ & $\begin{array}{l}2.2224 \\
(p=0.1413)\end{array}$ & $\begin{array}{l}4.6644 \\
(p=0.0348)\end{array}$ & $\begin{array}{l}3.6949 \\
(p=0.0593)\end{array}$ \\
\hline
\end{tabular}

Description: 2SLS estimation with two instruments, where group C regression control for the 30-day market return and 30-day IPO numbers prior to the IPO while group D regressions control for the 60-day variables. INIRE is the initial return of a company's IPO which is a common measure of IPO underpricing. UEO is the weighted average of urban economic openness which is the sum of a city's imports and exports as share of this city's GDP. The land-use right that a company owns in one city as a share of its overall land-use right is used as the weight. The instrumental variables for the $U E O$ is the natural logarithm of the disposable household income per capita and the weighted average distance between the city where the properties are and the nearest ports. $L N L A G$ is the natural logarithm of the time lag between issuing and listing dates. $L N P R O$ is the natural logarithm of the IPO proceeds. ROREA is the return on real estate assets of a company. LNAGE is the natural logarithm of the firm age for which it has been running as a real estate company before the IPO. STATEO is equal to 1 if the company is state-owned, 0 otherwise. CHINA is equal to 1 of the company is listed in Mainland China, 0 otherwise. MR30 and MR60 are 30- and 60-day market return before the IPO. DAY30 and DAY60 are the IPO numbers in 30 and 60 days prior to IPO respectively. z Standard errors are in the parentheses for 2 SLS regressions. ***, **, * denote significance at $1 \%, 5 \%$ or $10 \%$ respectively 
more for companies with higher returns. Durbin and Wu-Hausman statistics are also reported here to test for the exogeneity of UEO. Excluding model $\mathrm{J} 2$ (insignificant Durbin and Wu-Hausman statistics), all other models report significant statistics, suggesting that $U E O$ is indeed endogenous. The joint significance of the two instruments is considerably increased according to the statistics of the first-stage regressions reported in Panel A of Table 9. The R-squared increases by at least $42 \%$ and the F-test increases by at least $54 \%$.

As we have an over-identified case with two instrumental variables and one endogenous variable $(U E O)$, we can run the over-identifying restriction tests to determine whether the instrumental variable is uncorrelated with the error term (i.e. exogeneity of the instruments). The Sargan (1958) and Basmann (1960) Chi-squared statistics are calculated by regressing the sample residuals on the error term and the null hypothesis is "the instruments are exogenous". We report the Sargan and Basmann statistics in the Panel B of Table 9. If we exclude regression J1, all other models report insignificant statistics, suggesting that we cannot reject the null hypothesis of exogenous instruments. From the post-estimation tests on the quality of instruments, we conclude that jointly the two instruments are valid and effective for $U E O$ and the negative effect of UEO on IPO underpricing is robust.

\section{Conclusion}

As the extreme IPO underpricing in emerging markets is not fully explained by existing empirical studies using arguments valid in developed markets, we suggest an approach to improve the explanation of this phenomenon. This paper represents the first attempt to study the effect of the macroeconomy associated with the degree of urban economic openness on IPO underpricing. We analyse how the short-run IPO performance of companies with localised businesses is affected by the UEO of the regions where firms are invested. Higher UEO can lead to higher demand for real estate, or through the Balassa Samuelson effect, to higher wages in the non-tradable goods sector and hence to higher real estate prices. Moreover, an improvement in UEO can increase productivity, which is found to be a major determinant of a firm's profitability. All these channels may decrease the uncertainty regarding future profits and hence the IPO

Table 9 First-stage regression report and exogeneity test of instruments

\begin{tabular}{|c|c|c|c|c|}
\hline & $\mathrm{J} 1$ & $\mathrm{~J} 2$ & $\mathrm{~K} 1$ & $\mathrm{~K} 2$ \\
\hline \multicolumn{5}{|c|}{ Panel A: First stage regression report } \\
\hline$R$-squared & 0.3715 & 0.4128 & 0.3722 & 0.4039 \\
\hline$F$ test & 8.1672 & 10.0757 & 8.2073 & 9.7712 \\
\hline Prob $>F$ & 0.0007 & 0.0002 & 0.0007 & 0.0002 \\
\hline \multicolumn{5}{|c|}{ Panel B: Over - identification test (exogeneity of instruments) } \\
\hline \multicolumn{5}{|l|}{$p$-value } \\
\hline Sargan (score) & 0.0437 & 0.1957 & 0.1539 & 0.5340 \\
\hline Basmann & 0.0543 & 0.2253 & 0.1803 & 0.5637 \\
\hline
\end{tabular}


valuation of the company. As a result, issuers have less incentive to underprice IPO shares. Chinese real estate companies provide a suitable experimental laboratory to study the extremely large underpricing in developing markets, which cannot solely be accounted for by firm-specific characteristics. In fact, these firms show strong geographic investment patterns focused locally - usually at city level - and we also observe a highly heterogeneous degree of trade across Chinese cities.

Overall, we find that real estate companies in cities with higher UEO experience a smaller IPO underpricing. Signaling the importance of globalisation and economic integration. State-owned companies going public are found to experience higher underpricing than privately owned companies. Moreover, unlike previous studies, we show that 60- rather than 30-day market return is a better proxy for market sentiment and we attribute this to the immaturity of the Chinese IPO market. Finally, results are robust to the estimation of models with alternative specifications, including 2SLS models with disposable household income per capita and distance to ports as instruments.

To conclude, our results have implications for investors, owners and underwriters who may differentiate between IPOs of locally operating companies in more or less open regions. Our findings also provide policy implications focused on the ties between the local economy and its exposure to foreign trade as well as the performance of local firms.

Open Access This article is distributed under the terms of the Creative Commons Attribution 4.0 International License (http://creativecommons.org/licenses/by/4.0/), which permits unrestricted use, distribution, and reproduction in any medium, provided you give appropriate credit to the original author(s) and the source, provide a link to the Creative Commons license, and indicate if changes were made.

\section{References}

Allen, F., \& Faulhaber, G. R. (1989). Signalling by underpricing in the IPO market. Journal of Financial Economics, 23(2), 303-323.

Alt1, A. (2005). IPO market timing. Review of Financial Studies, 18(3), 1105-1138.

Balassa, B. (1964). The purchasing-power parity doctrine: A reappraisal. Journal of Political Economy, 72(6), 584-596.

Baltagi, B. H., Demetriades, P. O., \& Law, S. H. (2009). Financial development and openness: Evidence from panel data. Journal of Development Economics, 89(2), 285-296.

Basmann, R. L. (1960). On finite sample distributions of generalized classical linear identifiability test statistics. Journal of the American Statistical Association, 55(292), 650.

Bardhan, A. D., Edelstein, R. H., \& Leung, C. (2004). A note on globalization and urban residential rents. Journal of Urban Economics, 56(3), 505-513.

Bardhan, A., Edelstein, R., \& Tsang, D. (2008). Global financial integration and real estate security returns. Real Estate Economics, 36(2), 285-311.

Basu, P., \& Morey, M. R. (2005). Trade opening and the behavior of emerging stock market prices. Journal of Economic Integration, 20, 68-92.

Beatty, R. P., \& Ritter, J. R. (1986). Investment banking, reputation, and the underpricing of initial public offerings. Journal of Financial Economics, 15(1-2), 213-232.

Beck, T. (2002). Financial development and international trade is there a link ? Journal of International Economics, 57(1), 107-131.

Benveniste, L. M., \& Spindt, P. A. (1989). How investment bankers determine the offer price and allocation of new issues? Journal of Financial Economics, 24(2), 343-361.

Case, B., Goetzmann, W., \& Rouwenhorst, K. G. (1999). Global real estate markets: Cycles and fundamentals. 
Chan, S. H., Stohs, M. H., \& Wang, K. (2001). Are real estate IPOs a different species- evidence from Hong Kong IPOs. Journal of Real Estate Reseach, 21(3), 201-220.

Chan, K., Wang, J., \& Wei, K. C. J. (2004). Underpricing and long-term performance of IPOs in China. Journal of Corporate Finance, 10(3), 409-430.

Chang, E., Chen, C., Chi, J., \& Young, M. (2008). IPO underpricing in China: New evidence from the primary and secondary markets. Emerging Markets Review, 9(1), 1-16.

De Gregorio, J., Giovannini, A., Wolf, H., \& Gorden, R. (1994). International evidence on tradables and nontradables inflation: Comments. European Economic Review, 38, 1225-1256.

DeLoach, S. (2001). More evidence in favor of the Balassa-Samuelson hypothesis. Review of International Economics, 9, 336-342.

Demsets, H. (1973). Industry structure, market rivalry, and public policy. Journal of Law and Economics, 16(1), 1-9.

Dollar, D. (1992). Outward-oriented developing economies really do grow more rapidly: Evidence from 95 LDCs, 1976-1985. Economic Development and Cultural Change, 40, 523-544.

Edwards, S. (1998). Openness, productivity and growth: What do we really know? Economic Journal, 108, 383-398.

Eilon, S. (1985). A framework for profitability and productivity measures. Interfaces, 15(3), 31-40.

Fan, J., Wong, T., \& Zhang, T. (2007). Politically connected CEOs, corporate governance, and post-IPO performance of China's newly partially privatized firms. Journal of Financial Economics, 84(2), 330 357.

Gao, Y. (2010). What comprises IPO initial returns: Evidence from the Chinese market. Pacific-Basin Finance Journal, 18(1), 77-89.

$\mathrm{Gu}$, Y., \& Gao, T. (2007). The effect of exchange rate volatility on the foreign trade volume in China (Chinese). The World Economy, 10, 49-57.

Jiang, Y. (2011). Understanding openness and productivity growth in China: An empirical study of the Chinese provinces. China Economic Review, 22(3), 290-298.

Jovanovic, B. (1982). Selection and the evolution of industry. Econometrica, 50(3), 649-670.

Kim, D.-H., Lin, S.-C., \& Suen, Y.-B. (2012). The simultaneous evolution of economic growth, financial development, and trade openness. The Journal of International Trade \& Economic Development, 21(4), 513-537.

Kukeli, A. (2012). Capital formation in transition economies : Empirical evidence on the effect of openness. International Journal of Business \& Economics Perspectives, 7(1), 48-58.

Law, S. H. (2008). Does a Country's openness to trade and capital accounts lead to financial development? Evidence from Malaysia. Asian Economic Journal, 22(2), 161-177.

Li, K., Morck, R., Yang, F., \& Yeung, B. (2004). Firm-specific variation and openness in emerging markets. The Review of Economics and Statistics, 86(3), 658-669.

Lim, K.-P., \& Kim, J. H. (2011). Trade openness and the informational efficiency of emerging stock markets. Economic Modelling, 28(5), 2228-2238.

Loughran, T., \& Ritter, J. R. (2002). Why don ' $t$ issuers get upset about leaving money on the table in IPOs ? Review of Financial Studies, 15(2), 413-443.

Miao, T., \& Zhu, C. (2005). Regional pattern analysis of China's real estate market. Economic Geography (Chinese), 25(3).

Miller, S. M., \& Upadhyay, M. P. (2000). The effects of openness, trade orientation, and human capital on total factor productivity. Journal of Development Economics, 63(2), 399-423.

Mok, H. M. K., \& Hui, Y. V. (1998). Underpricing and aftermarket performance of IPOs in Shanghai, China. Pacific-Basin Finance Journal, 6(5), 453-474.

Peltzman, S. (1977). Gain and losses from industrial concentration. Journal of Law and Economics, 20(2), 229-263.

Rajan, R. G., \& Zingales, L. (2003). The great reversals: The politics of financial development in the twentieth century. Journal of Financial Economics, 69(1), 5-50.

Rock, K. (1986). Why new issues are underpriced. Journal of Financial Economics, 15(1-2), 187-212.

Sachs, J., \& Warner, A. (1995). Economic reform and the process of global integration. Brookings Papers on Economic Activity, 1, 1-118.

Saleryd, H., \& Vlachos, J. (2002). Markets for risk and openness to trade: How are they related. Journal of International Economics, 57.

Samuelson, P. A. (1964). Notes on trade problems theoretical. The Review of Economics and Statistics, 46(2), $145-154$.

Sargan, J. D. (1958). The estimation of economic relationships using instrumental variables. Econometrica, $26(3), 393$. 
Stierwald, A. (2010). Determinants of profitability: An analysis of large Australian firms.

Su, C., \& Bangassa, K. (2011). The impact of underwriter reputation on initial returns and long-run performance of Chinese IPOs. Journal of International Financial Markets, Institutions \& Money, 21(5), 760-791.

Tian, L. (2011). Regulatory underpricing: Determinants of Chinese extreme IPO returns. Journal of Empirical Finance, 18(1), 78-90.

Wang, S., Yang, Z., \& Liu, H. (2011). Impact of urban economic openness on real estate prices: Evidence from thirty-five cities in China. China Economic Review, 22(1), 42-54.

Wong, S. K., Wei, Q., \& Chau, K. W. (2013). IPO location as a quality signal: The case of Chinese developers. The Journal of Real Estate Finance and Economics, 47(4). 